\title{
Two new free-living nematode species of Setosabatieria (Comesomatidea) from the East China Sea and the Chukchi Sea
}

\author{
Y.Q. Guo ${ }^{\mathrm{a}}$, D.Y. Huang ${ }^{\mathrm{b}}$, Y.Z. Chen ${ }^{\mathrm{a}}$, J.J. Wang ${ }^{\mathrm{b}}$ and R.C. Lin ${ }^{\mathrm{b}}$ * \\ ${ }^{a}$ Key Laboratory of Marine fishery resources and Ecological Environment of Fujian Province, \\ Fisheries College, Jimei University, Xiamen, PR China, ${ }^{b}$ Third Institute of Oceanography, State \\ Oceanic Administration, Xiamen, PR China
}

(Received 21 April 2014; accepted 7 January 2015; first published online 25 March 2015)

\begin{abstract}
Two new free-living marine nematode species of the genus Setosabatieria from the sandy intertidal zone of Xiamen, in the East China Sea and a shallow water area in the Chukchi Sea, Arctic Ocean are described and illustrated. Setosabatieria longiapophysis sp. nov. is characterized by four longitudinal files with 7-9 cervical setae per file, 15-16 minute papillate precloacal supplements and relatively long straight apophyses of gubernaculum. Setosabatieria major sp. nov. is identified by its relatively large body of $2701-3144 \mu \mathrm{m}$, the number (10-11) of cervical setae per file, 26-28 minute papillate precloacal supplements and spicules with a central septum at both the proximal and distal end. A pictorial identification key to all known species of Setosabatieria is provided.
\end{abstract}

http://zoobank.org/urn:lsid:zoobank.org:pub:B8A2BEC9-5CD4-4AA9-9CA8D1AE1FDE4887

Keywords: Setosabatieria longiapophysis sp. nov.; Setosabatieria major sp. nov.; pictorial key

\section{Introduction}

Setosabatieria was first erected by Platt (1985) to accommodate two Sabatieria species possessing synapomorphic features warranting recognition as a separate genus, namely the lack of cuticular punctations and the presence of four sublateral files of numerous long cervical setae (Platt 1985). To date, eight species of Setosabatieria with distinct differentiating morphology have been reported from oceans worldwide (Gagarin 2013). Leduc et al. (2012) provided a dichotomous key to the genus based on tail shape, spicule shape, and the number of windings of amphidial fovea and precloacal supplements. Two new Setosabatieria species from the sandy intertidal zone of Xiamen in the East China Sea and a shallow water area in the Chukchi Sea, Arctic Ocean are described and illustrated in this paper.

\section{Methods}

Nematode samples from Xiamen, East China Sea were collected in October 2011 from the sandy intertidal zone at Guliang Island. Sediments from the Chukchi Sea, Arctic Ocean were collected using a multicorer during the Fourth Chinese National Arctic Research Expedition from July to September, 2010. The samples were fixed

*Corresponding author. Email: linrongcheng@tio.org.cn 
with $5 \%$ formalin in seawater. In the laboratory, the samples were stained with rose Bengal for more than $24 \mathrm{~h}$. Nematodes were extracted from the sediment by decantation and/or Ludox centrifugation (Warwick et al. 1998). Each extracted sample was washed into a lined Petri dish and the meiofauna were sorted under a stereoscopic microscope to higher taxonomic levels. Nematodes were transferred into an embryo glass dish containing by volume 5\% glycerine, 5\% pure ethanol, $90 \%$ freshwater, and left in a desiccator for a few days. This allows the ethanol and water to evaporate slowly leaving the nematodes in pure glycerol. The descriptions have been made from glycerine mounts using interference contrast microscopy (NIKON 80i, Shizuoka, Japan). Drawings were made with the aid of a camera lucida. Type specimens are deposited in the Institute of Oceanology, Chinese Academy of Sciences.

Measurements are in $\mu \mathrm{m}$. Abbreviations are as follows: $a$, total body length divided by maximum body diameter; $b$, total body length divided by pharynx length; $c$, total body length divided by tail length; a.b.d., anal body diameter; $c^{\prime}$, tail length divided by a.b.d.; Spic, spicule length as chord; Tl, total body length; Hd, head diameter as percentage of body diameter at level posterior pharynx; $\mathrm{A} \%$, amphid diameter as percentage of corresponding body diameter; At, number of turns of amphidial fovea; R3, cephalic setae length as percentage of head diameter; Cs, number of cervical setae in each sublateral row; Ps, number of precloacal supplements; $\mathrm{V} \%$, position of vulva from anterior as percentage of total body length.

\section{Description}

Family COMESOMATIDAE Filipjev, 1918

Genus Setosabatieria Platt, 1985

Setosabatieria longiapophysis sp. nov. (Figures 1, 2 and Table 1)

\section{Type material}

Five males and two females were collected from station XMGLY L2. Holotype: $\precsim 1$ on slide number XMGLY20111016 L206.

Paratypes: §2 and $\$ 2$ on slide number XMGLY20111016 L205, ð3 on XMGLY20111016 L210, §4 on XMGLY20111016 L218, §5 and +1 on XMGLY20111016 L213.

\section{Type locality and habitat}

Intertidal sandy sediment at Gulang Island, Xiamen, the East China Sea. Latitude: $118.0666^{\circ} \mathrm{E}$, longitude: $24.4333^{\circ} \mathrm{N}$.

Characteristics of surface sediment: Silt + clay $0.07 \%$, salinity $20-22 \%$, total organic matter $0.0192 \%$.

\section{Etymology}

This species is named for the long straight apophyses of gubernaculum.

Figure 1. Setosabatieria longiapophysis sp. nov. (A) lateral view of male head end; (B) lateral view of female anterior region; (C) lateral view of male tail region and copulatory apparatus; (D) lateral view of female tail region. Scale bars: $A=20 \mu \mathrm{m} ; \mathrm{B}, \mathrm{C}=25 \mu \mathrm{m} ; \mathrm{D}=50 \mu \mathrm{m}$. 


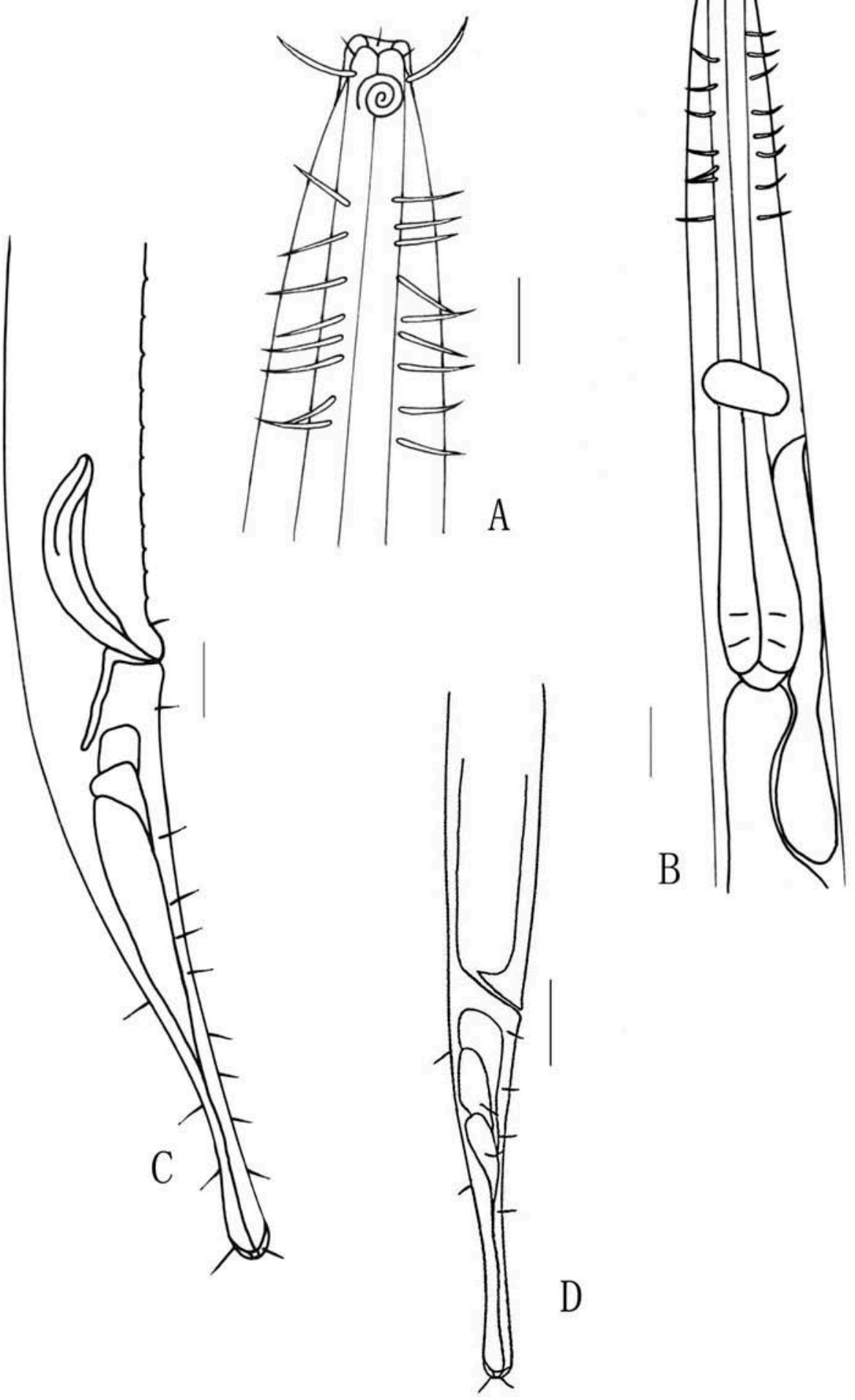




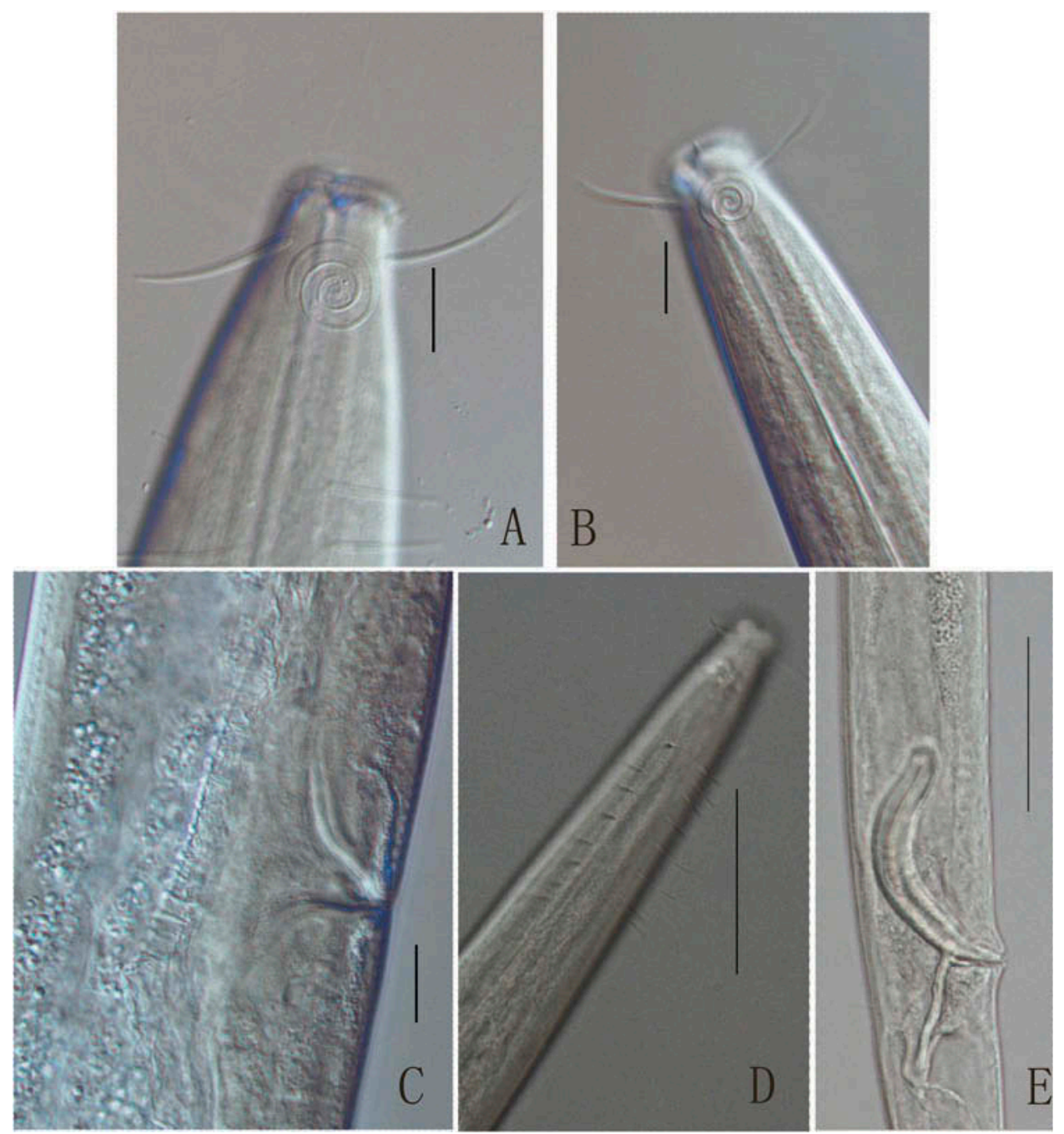

Figure 2. Setosabatieria longiapophysis sp. nov. (A) lateral view of male head end, showing amphidial fovea and cephalic setae; (B) lateral view of female head end; (C) lateral view of female vulva region; (D) lateral view of male head end, showing cervical setae; (E) lateral view of male spicule, gubernaculum and precloacal supplements. Scale bars: $A-C=10 \mu \mathrm{m}$, $\mathrm{D}, \mathrm{E}=50 \mu \mathrm{m}$.

\section{Measurements}

Measurements are given in Table 1.

$$
\begin{aligned}
& \text { Holotype } \delta 1: \quad \frac{-252 \mathrm{~W} 2273}{16414939} \quad 2480 \mu \mathrm{m} ; \mathrm{a}=50.6, \mathrm{~b}=9.8, \mathrm{c}=12.0, \text { Spic }=66.0 \mu \mathrm{m} \\
& \text { Paratype }+1: \quad \frac{-270 \mathrm{~V} 2312}{16415138} \quad 2540 \mu \mathrm{m} ; \mathrm{a}=49.8, \mathrm{~b}=9.4, \mathrm{c}=11.2, \mathrm{~V} \%=50.0 \%
\end{aligned}
$$


Table 1. Individual measurements of Setosabatieria longiapophysis sp. nov. (in $\mu \mathrm{m}$ ).

\begin{tabular}{|c|c|c|c|c|c|c|c|}
\hline \multirow[t]{2}{*}{ Characters } & \multirow{2}{*}{$\frac{\text { Holotype }}{\lesssim 1}$} & \multicolumn{6}{|c|}{ Paratypes } \\
\hline & & 32 & †3 & 万 4 & 35 & 우 1 & q 2 \\
\hline Total body length & 2480 & 2435 & 2590 & 2380 & 2800 & 2540 & 2810 \\
\hline Head diameter & 16 & 16 & 15 & 15 & 17 & 16 & 17 \\
\hline Amphids diameter & 11 & 10 & 10 & 10 & 10 & 7.8 & 9.2 \\
\hline $\begin{array}{l}\text { Body width level } \\
\text { amphid }\end{array}$ & 16 & 15 & 15 & 15 & 17 & 16 & 17 \\
\hline Length of cephalic setae & 18 & 19 & 17 & 18 & 17 & 16 & 18 \\
\hline $\begin{array}{l}\text { Nerve ring from the } \\
\text { anterior end }\end{array}$ & 169 & 163 & 164 & 161 & 164 & 166 & 175 \\
\hline $\begin{array}{l}\text { Body width level nerve } \\
\text { ring }\end{array}$ & 38 & 36 & 38 & 35 & 38 & 37 & 39 \\
\hline Pharynx length & 252 & 262 & 270 & 259 & 261 & 270 & 271 \\
\hline $\begin{array}{c}\text { Body width level } \\
\text { pharynx end }\end{array}$ & 41 & 41 & 43 & 40 & 43 & 41 & 44 \\
\hline $\begin{array}{l}\text { Maximum body } \\
\text { diameter }\end{array}$ & 49 & 42 & 48 & 53 & 54 & 51 & 58 \\
\hline $\begin{array}{l}\text { Spicule length as chord } \\
\text { (Spic) }\end{array}$ & 66 & 65 & 64 & 67 & 66 & - & - \\
\hline Spicule length as arc & 80 & 80 & 78 & 77 & 78 & - & - \\
\hline $\begin{array}{l}\text { Length of gubernaculum } \\
\text { apophysis }\end{array}$ & 36 & 35 & 37 & 31 & 33 & - & - \\
\hline Anal diameter & 39 & 38 & 40 & 40 & 41 & 38 & 41 \\
\hline Tail length & 206 & 227 & 217 & 223 & 222 & 227 & 237 \\
\hline $\begin{array}{l}\text { Tail length/anal body } \\
\text { diameter }\end{array}$ & 5.3 & 6.0 & 5.4 & 5.6 & 5.4 & 6.0 & 5.8 \\
\hline Vulva from anterior end & - & - & - & - & - & 1270 & 1370 \\
\hline Body width level vulva & - & - & - & - & - & 49 & 52 \\
\hline $\mathrm{V} \%$ & - & - & - & - & - & 50 & 49 \\
\hline $\mathrm{a}$ & 50.6 & 57.9 & 53.9 & 44.9 & 51.8 & 49.8 & 48.5 \\
\hline $\mathrm{b}$ & 9.8 & 9.3 & 9.6 & 9.2 & 10.7 & 9.4 & 10.4 \\
\hline c & 12.0 & 10.7 & 11.9 & 10.7 & 12.6 & 11.2 & 11.9 \\
\hline
\end{tabular}

\section{Description}

Body cylindrical, tapering towards both extremities, maximum body diameter 42-58 $\mu \mathrm{m}$. Cuticle not punctate but with faint transverse striations visible throughout body. Head narrower than rest of body due to constriction at level of amphidial fovea. Buccal cavity cup-shaped. Inner labial sensilla not visible, outer labial sensilla setiform, $2 \mu \mathrm{m}$ long. Four cephalic setae 16-19 $\mu \mathrm{m}$ long $(100-120 \%$ of head diameter). Cervical setae, similar to cephalic setae length, arranged in four longitudinal files of seven to nine setae. Amphidial fovea spiral, with 2.75-3 turns, 15-17 $\mu \mathrm{m}$ in diameter, occupying $49-69 \%$ of corresponding body diameter. Pharynx gradually enlarging posteriorly but without true terminal bulb. Nerve ring at $61-65 \%$ of pharynx length from anterior end. Cardia small, muscular, surrounded by intestinal tissue. Excretory pore posterior to nerve ring. Tail conico-cylindrical, 
5.3-6.0 times anal body diameter, with numerous caudal setae. Tail tip enlarged with three terminal setae $12 \mu \mathrm{m}$ long. Caudal glands and spinneret well developed.

Males. Testes opposite and outstretched. Anterior testis situated to left of intestine, posterior testis to right. Spicules paired, equal, arcuate, with slightly marked capitulum and a central cuticularized septum at the proximal end. Gubernaculum with 31-37 $\mu \mathrm{m}$ long straight dorsocaudal directed apophyses. Fifteen or 16 poorly developed small precloacal papillate supplements, posterior supplements with closer spacing.

Females. Similar to male in general characteristics, but amphid diameter smaller; vulva at $49-50 \%$ of total body length but developed reproductive system not found.

\section{Differential diagnosis}

Setosabatieria longiapophysis sp. nov. is similar to Setosabatieria triangularis Riera et al. 2006 in that they both have longer cephalic setae than in the other species, and a similar number of cervical setae in each sublateral row and precloacal supplements (Table 3). However, Setosabatieria longiapophysis sp. nov. has spicules with straight apophyses $31-37 \mu \mathrm{m}$ long in contrast to the triangular apophyses of S. triangularis.

Setosabatieria major sp. nov. (Figures 3, 4 and Table 2)

\section{Type material}

Five males, one female and one juvenile from station CC4. Holotype: $\widehat{\jmath} 1$ on slide number Chukchi20100720 CC42401.

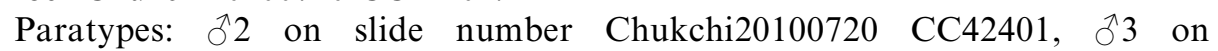
Chukchi20100720 CC42403, §4 on Chukchi20100720 CC42404, §5 on Chukchi20100720 CC42405, +1 on Chukchi20100720 CC42406, juvenile on Chukchi20100720 CC42407.

\section{Type locality and habitat}

Sublittoral zone in the Chukchi Sea (the Arctic Ocean). Latitude: $68.1336^{\circ} \mathrm{N}$, longitude: $167.8633^{\circ} \mathrm{W}$.

Environmental parameters: water depth $52 \mathrm{~m}$, surface water temperature $2.2^{\circ} \mathrm{C}$, salinity at $52 \mathrm{~m}$ depth $32.13 \%$.

\section{Etymology}

This species is named for the large body.

Figure 3. Setosabatieria major sp. nov. (A) lateral view of male head end; (B) lateral view of female anterior region; (C) lateral view of male tail and copulatory apparatus; (D) spicule and gumbernaculum; (E) lateral view of female tail region. Scale bars: $A, D=20 \mu \mathrm{m} ; \mathrm{B}, \mathrm{C}, \mathrm{E}=50 \mu \mathrm{m}$. 


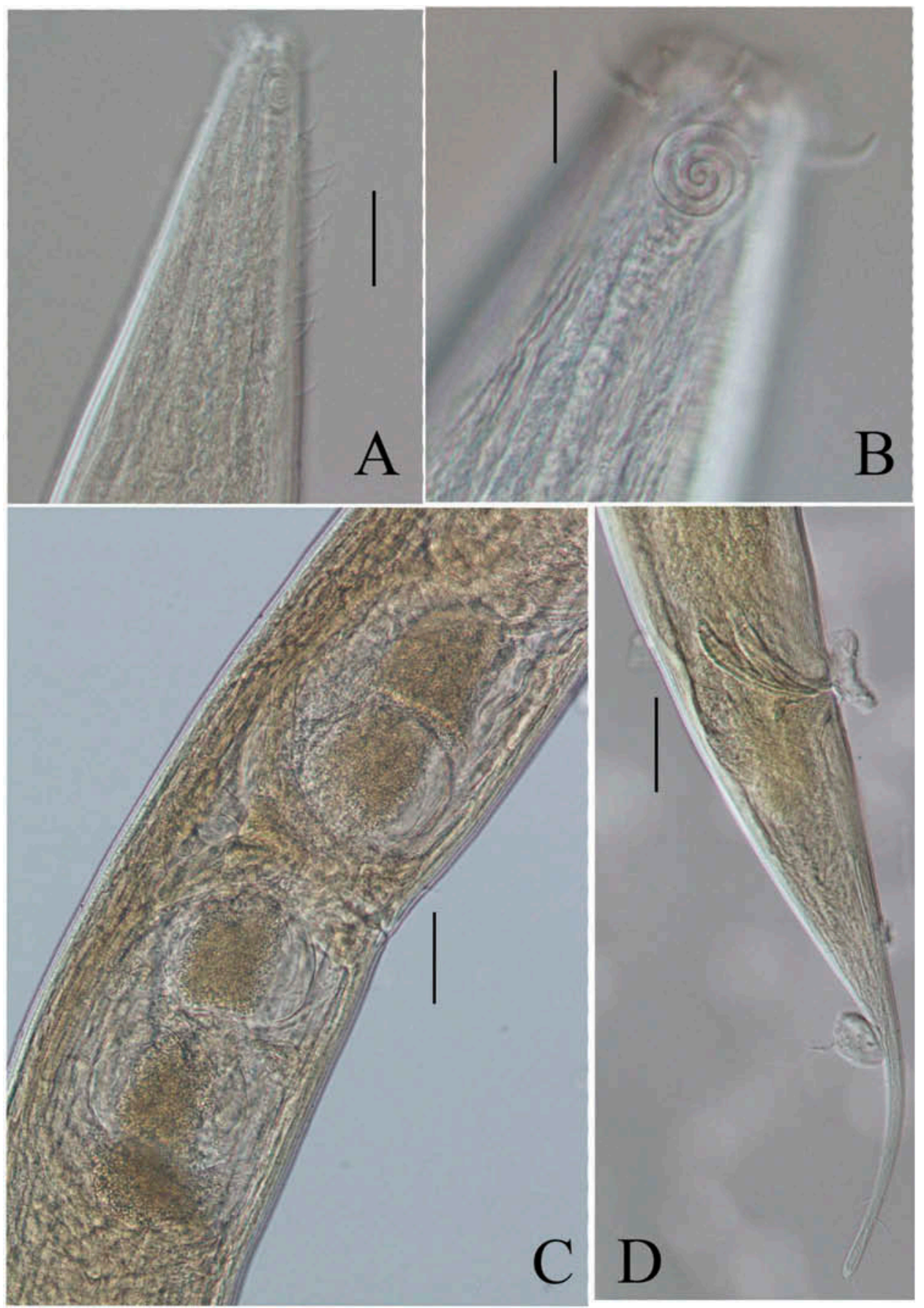

Figure 4. Setosabatieria major sp. nov. (A) lateral view of male head end, showing cervical setae; (B) lateral view of female head end, showing female amphidial fovea; (C) lateral view of female vulva region, showing vulva and eggs; (D) lateral view of male tail region. Scale bars: $\mathrm{A}=25 \mu \mathrm{m} ; \mathrm{B}=10 \mu \mathrm{m} ; \mathrm{C}, \mathrm{D}=50 \mu \mathrm{m}$. 
Table 2. Individual measurements of Setosabatieria major sp. nov. (in $\mu \mathrm{m}$ ).

\begin{tabular}{|c|c|c|c|c|c|c|c|}
\hline \multirow[t]{2}{*}{ Characters } & \multirow{2}{*}{$\frac{\text { Holotype }}{\lesssim 1}$} & \multicolumn{6}{|c|}{ Paratypes } \\
\hline & & 32 & †3 & $\widehat{\partial} 4$ & 55 & q1 & Juvenile \\
\hline Total body length & 3130 & 2720 & 3075 & 2930 & 2700 & 3145 & 1730 \\
\hline Head diameter & 21 & 20 & 22 & 24 & 19 & 23 & 17 \\
\hline Amphids diameter & 12 & 10 & 13 & 14 & 12 & 12 & 8.5 \\
\hline $\begin{array}{l}\text { Body width level } \\
\text { amphid }\end{array}$ & 22 & 20 & 24 & 26 & 21 & 26 & 9 \\
\hline $\begin{array}{l}\text { Length of cephalic } \\
\text { setae (R3) }\end{array}$ & 9 & 11 & 11 & 10 & 9 & 11 & 13 \\
\hline $\begin{array}{l}\text { Nerve ring from the } \\
\text { anterior end }\end{array}$ & 206 & 172 & 199 & 200 & 154 & 188 & 115 \\
\hline $\begin{array}{l}\text { Body width level nerve } \\
\text { ring }\end{array}$ & 96 & 79 & 76 & 62 & 61 & 75 & 55 \\
\hline Pharynx length & 366 & 292 & 327 & 327 & 282 & 332 & 231 \\
\hline $\begin{array}{l}\text { Body width level } \\
\text { pharynx end }\end{array}$ & 117 & 97 & 103 & 93 & 74 & 104 & 70 \\
\hline $\begin{array}{l}\text { Maximum body } \\
\text { diameter }\end{array}$ & 168 & 122 & 136 & 122 & 106 & 176 & 78 \\
\hline $\begin{array}{l}\text { Spicule length as chord } \\
\text { (Spic) }\end{array}$ & 69 & - & 69 & 78 & 70 & - & - \\
\hline Spicule length as arc & 74 & - & 73 & 87 & 73 & - & - \\
\hline $\begin{array}{l}\text { Length of gubernaculum } \\
\text { apophysis }\end{array}$ & 17 & - & 23 & 18 & 23 & - & - \\
\hline Anal diameter & 82 & 76 & 72 & 68 & 64 & 80 & 46 \\
\hline Tail length & 323 & 290 & 325 & 296 & 241 & 316 & 206 \\
\hline Tail length/a.b.d. & 4.0 & 3.8 & 4.5 & 4.4 & 3.7 & 4.0 & 4.5 \\
\hline $\begin{array}{l}\text { Vulva from anterior } \\
\text { end }\end{array}$ & - & - & - & - & - & 1390 & - \\
\hline Body width level vulva & - & - & - & - & - & 164 & - \\
\hline $\mathrm{V} \%$ & - & - & - & - & - & 44 & - \\
\hline $\mathrm{a}$ & 18.6 & 22.3 & 22.7 & 24.0 & 25.4 & 17.9 & 22.2 \\
\hline $\mathrm{b}$ & 8.6 & 9.3 & 9.4 & 8.9 & 9.6 & 9.5 & 7.5 \\
\hline $\mathrm{c}$ & 9.7 & 9.4 & 9.5 & 9.9 & 11.2 & 10.0 & 8.4 \\
\hline
\end{tabular}

\section{Measurements}

Measurements are given in Table 2.

$$
\begin{aligned}
& \text { Holotype } \precsim 1: \quad \frac{-366 \mathrm{~W} 2806}{2111716882} \quad 3130 \mu \mathrm{m} ; \mathrm{a}=18.6, \mathrm{~b}=8.6, \mathrm{c}=9.7, \text { Spic }=69 \mu \mathrm{m} \\
& \text { Paratype } \text { \&1: } \quad \frac{-332 \mathrm{~V} 2828}{2310417680} \quad 3145 \mu \mathrm{m} ; \mathrm{a}=17.9, \mathrm{~b}=9.5, \mathrm{c}=8.0, \mathrm{~V} \%=44.1 \%
\end{aligned}
$$

\section{Description}

Body rather large cylindrical, tapering towards both extremities. Cuticle not punctated but with transverse striation most obvious at anterior and posterior 
extremities. Buccal cavity small cup-shaped, surrounded by six short outer labial, 1.5-2 $\mu \mathrm{m}$ long and four cephalic setae, 9-13 $\mu \mathrm{m}$ long. Amphidial fovea spiral, with 3.25-3.75 turns and occupying $47-57 \%$ of corresponding body diameter. Four sublateral rows of $10-11$ cervical setae $8-10 \mu \mathrm{m}$ long. Pharynx gradually swollen posteriorly, not forming a true bulb. Cardia small, muscular, surrounded by intestinal tissue. Ventral gland situated posterior to pharynx and excretory pore about level nerve ring. Nerve ring at 55-61\% of pharynx length from anterior end. Tail slender, with rather broad, conical anterior portion and rather narrow cylindrical posterior portion. Tail 3.7-4.5 times of the anal body diameter with numerous short setae. Tail tip not enlarged, with $15 \mu \mathrm{m}$ long three terminal setae. Caudal glands not always visible and spinneret well developed.

Males. Reproductive system with two opposite outstretched testes. Spicules paired, equal, slight arcuate, 0.9-1.3 times as long as cloacal body diameter, with central septum appearing in both proximal and distal portions. Gubernaculum with a pair of short dorsocaudal apophyses. There are 26-28 small pre-cloacal papillae supplements, although they are very small and difficult to observe.

Females. Similar to male in general characteristics, but tail with fewer short setae and narrow cylindrical posterior portion longer than anterior conical portion. Reproductive system with two outstretched equally developed ovaries. Vulva at $44 \%$ of total body length.

\section{Differential diagnosis}

Setosabatieria major sp. nov. is characterized by its rather large body (length 2700$3145 \mu \mathrm{m}$; maximum body diameter $106-176 \mu \mathrm{m})$, the number $(10-11)$ of cervical setae per file, 26-28 small papillate precloacal supplements and central septum appearing in both proximal and distal portions of spicules. These characters are obviously different from those of other species in this genus.

\section{Discussion}

Setosabatieria longiapophysis sp. nov. was found in the samples from low tidal level where $38 \%$ of the specimens were free-living nematodes, It accounted for $1 \%$ of the total number of nematodes. Setosabatieria major sp. nov. was found in subsurface sediments at $2-4 \mathrm{~cm}$ depth. It accounted for $3 \%$ of total nematode abundance at the type locality CC4 station (Lin et al. 2014). At present, the three species of Setosabatieria found in China are distributed in three distant sea areas: Bohai, the Yellow Sea and the East China Sea. The geographic distributions of other valid species in the genus are given by Gagarin (2013) and Platt (1985). The genus has a worldwide distribution. The dichotomous keys including seven species in this genus were provided by Leduc et al. (2012). Composite differentiating characters of all known male Setosabatieria species are provided as an aid to identification (Table 3). Based on Gagarin (2013), the pictorial key of the genus is shown in Figure 5. 


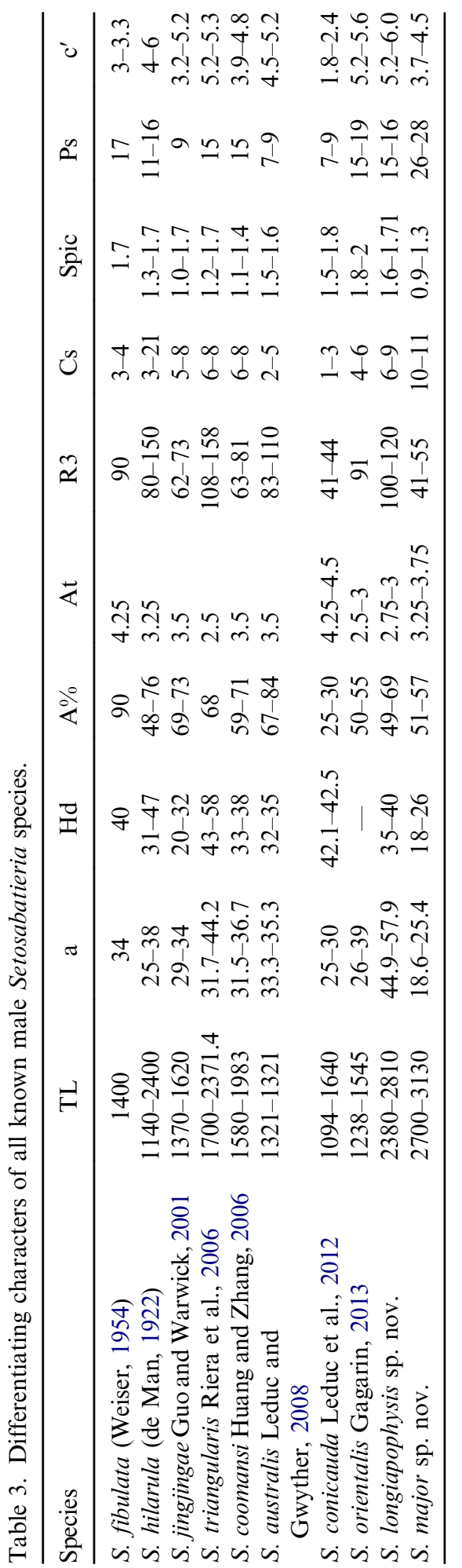




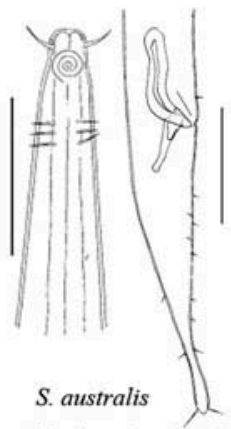

(apud Leduc, Gwyther,2008) (apud Leduc, Probert,Nodder,2012) (apud Huang,Zhang,2006) Scale bar: $\mathrm{Head}=50 \mu \mathrm{m}$ Tail $=50 \mu \mathrm{m}$

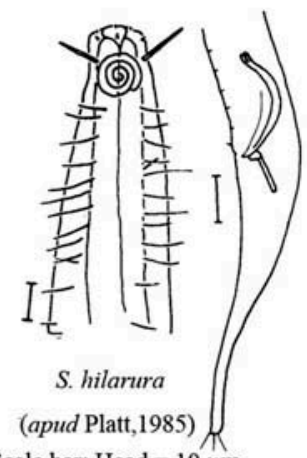

Scale bar: Head $=10 \mu \mathrm{m}$ Tail $=30 \mu \mathrm{m}$

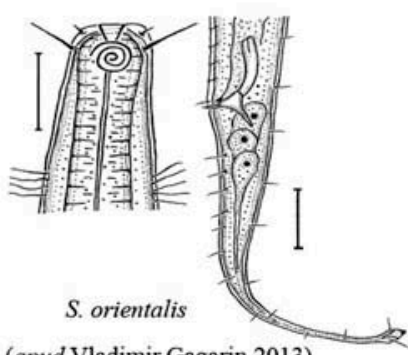
(apud Vladimir,Gagarin,2013) Scale bar: Head $=10 \mu \mathrm{m}$ Tail $=30 \mu \mathrm{m}$

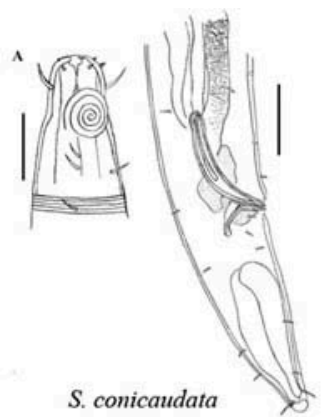

Scale bar: $\mathrm{Head}=20 \mu \mathrm{m}$ Tail $=30 \mu \mathrm{m}$

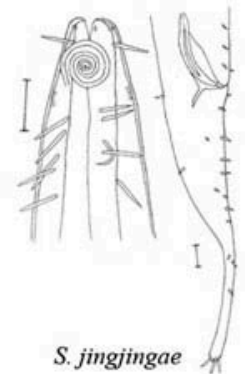

(apud Guo,Warwick,2001) Scale bar: Head $=10 \mu \mathrm{m}$ Tail $=10 \mu \mathrm{m}$

S. longiapophysis sp. nov. original

Scale bar: Head $=20 \mu \mathrm{m}$ Tail $=25 \mu \mathrm{m}$

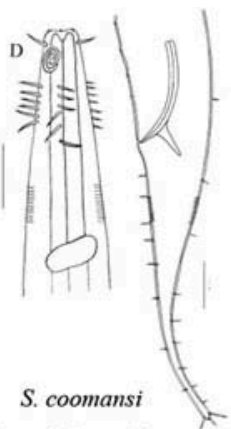

Scale bar: $\mathrm{Head}=30 \mu \mathrm{m}$ Tail $=30 \mu \mathrm{m}$

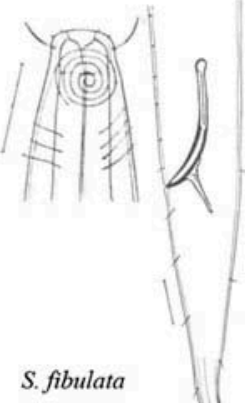

(apud Wieser,1954)

Scale bar: $\mathrm{Head}=20 \mu \mathrm{m}$ Tail $=20 \mu \mathrm{m}$

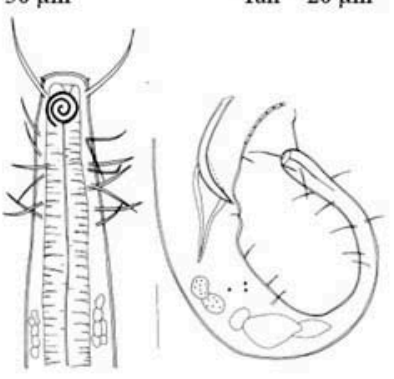

S. triangularis

(apud Riera,Nuhez,Brito,2006) Scale bar: Head $=13 \mu \mathrm{m}$ Tail $=16 \mu \mathrm{m}$

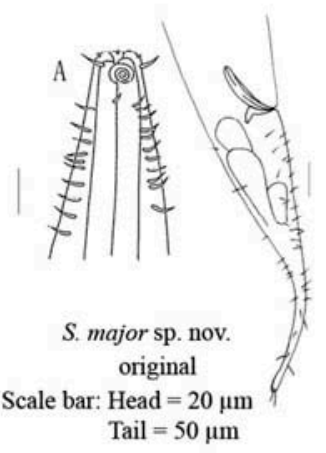

Figure 5. Pictorial key for valid species of genus Setosabatieria.

\section{Disclosure statement}

No potential conflict of interest was reported by the authors.

\section{Funding}

This work was supported by grants from the National Science Foundation of China [No. 41176107]; Polar Environment Comprehensive Investigation and Assessment 
Programmes [No. CHINARE 2013-03-05]; the Ocean Public Welfare Scientific Research Project of China [No. 201105022-2]; the Polar Science Strategic Research Foundation of China [No. 20120105]; and the Training Program of Fujian Excellent Talents in University.

\section{References}

de Man JG. 1922. Neue freilebende Nematoden aus der Zuidersee. Tidschrift der Nederlandsche Dierkundige Vereeniging. 2:124-134.

Filipjev IN. 1918. Free living marine nematodes of the Sevastopol area. Trudy osob Zoology Laboratory Sebastopol Biology Station. 2:1-350.

Gagarin VG. 2013. Four new species of free-living marine nematodes of the family Comesomatidae (Nematoda: Araeolaimida) from coast of Vietnam. Zootaxa. 3608:547-560.

Guo YQ, Warwick RM. 2001. Three new species of free-living nematodes from the Bohai Sea, China. J Nat Hist. 35:1575-1586.

Huang Y, Zhang ZN. 2006. New species of free-living marine nematodes from the Yellow Sea, China. J Mar Biol Assoc UK. 86:271-281.

Leduc D, Gwyther J. 2008. Description of new species of Setosabatieria and Desmolaimus (Nematoda: Monhysterida) and a checklist of New Zealand free-living marine nematode species. N Z J Mar Freshw Res. 42:339-362.

Leduc D, Probert PK, Nodder SD. 2012. Two new free-living nematode species (Comesomatidae) from the continental slope of New Zealand, with keys and notes on distribution. Zootaxa. 3348:40-55.

Lin RC, Huang DY, Guo YQ, Cao YK, Wang JJ. 2014. Abundance and distribution of meiofauna in the Chukchi Sea. Acta Oceanologica Sinica. 33:90-94.

Platt HM. 1985. The free-living marine nematode genus Sabatieria (nematoda, Comesomatidae) - Taxonomic revision and pictorial keys. Zool J Linn Soc. 83:27-78.

Riera R, Nunez J, Brito M. 2006. Two new species of Comesomatidae Filipjev, 1922 (Nematoda: Chromadorida) from sandy bottoms of Tenerife, Canary Islands. Zootaxa. 1126:53-61.

Warwick RM, Platt HM, Somerfield PJ. 1998. Synopses of the British Fauna (New Series). In: Barnes RSK, Crothers JH, editors. No. 53, Free-living Marine Nematodes, Part III, Monhysterids. London: Published for the Linnean Society of London and the Estuarine and Coastal Sciences Association by Field Studies Council.

Wieser W. 1954. Free-living marine nematodes. II. Chromadoroidea. Acta Universitis Lundensis. 50:1-148. 